\title{
Penggunaan Media Whatsapp Dalam Pembelajaran Sejarah Islam Indonesia Selama Pandemi Covid-19 (Mahasiswa Semester Dua Prodi Akidah Dan Filsfat Islam )
}

\author{
Reni Fitria ${ }^{1}$, Muhammad Fahmi Jazuli ${ }^{2}$, Moch. Abu Fadlol ${ }^{3}$ \\ Universitas Islam Negeri Sunan Kalijaga
}

\begin{tabular}{l}
\hline \hline Article Info \\
\hline Article history: \\
Accepted: 05 Januari 2022 \\
Publish: 08 Januari 2022 \\
\\
Keywords: \\
WhatsApp media, learning, covid- \\
19 pandemic
\end{tabular}

Article Info

Article history:

Diterima: 05 Januari 2022

Terbit: 08 Januari 2022

\begin{abstract}
Abstract The policy of the minister of education and culture regarding distance learning requires educators to be more creative in using learning media. Currently, there are many applications that can be used as learning media such as WhatsApp. This study aims to determine the effectiveness of using WhatsApp in learning during the pandemic, the obstacles faced and solutions to overcome these obstacles. This research is included in the type of descriptive research and data collection methods by observation, interviews, anget and documentation. The results of the study show that the WhatsApp application is quite effective for learning media although in its use there are still some obstacles.
\end{abstract}

\begin{tabular}{l} 
Abstract \\
Kebijakan menteri pendidikan dan kebudayaan tentang pembelajaran jarak \\
jauh menuntut pendidik untuk lebih kretaif dalam menggnakan media \\
pembelajaran. saat ini sudah banyak aplikasi yang dapat dijadikan media \\
pembelajaran seperti whatssapp. Penelitian ini bertujuan untuk mengetahui \\
efetivitas penggunaan WhatsApp dalam pembelajaran selama pandemi, \\
hambatan yang dihadapi dan solusi solusi untuk mengatasi hambatan tersebut. \\
Penelitian ini termasuk kedalam jenis penelitian deskrptif dan metode \\
pengmpulan data dengan observasi, wawancara, anget dan dokumentasi. \\
Hasil penelitia mennjukan bahwa aplikasi WhatsApp cukup efektif untuk \\
media pembelajaran meskipun dalam penggunaannya masih ditemukan \\
beberapa kendala. \\
\hline This is an open access article under the Lisensi Creative Commons Atribusi- \\
BerbagiSerupa 4.0 Internasional \\
\hline ga () \\
\hline SA
\end{tabular}

\section{PENDAHULUAN}

Keputusan strategis bangsa untuk terus memperbaiki sektor pendidikan merupakan langkah yang sangat cerdas, karena pendidikan bisa membawa perubahan bagi masyarakat. Semakin baik pendidikan mereka, maka akan semakin luas wawasannya, tinggi kreatifitas, dan keahliannya. Dengan tingginya kahlian maka akan semakin tinggi pula produktivitasnya untuk kemajuan ekonomi bangsa. Sangat jelas bahwa tujuan pemerintah menerapkan kebijakankebijakan pendidikan tidak lain adalah agar generasi penerus bangsa mempunyai wawasan individu, daya saing, dan prestasi, terutama bagi pembangunan bangsa dan negara. Kebijakan yang dicetusan pemerintah juga dengan memperhatikan situasi, kondisi dan juga sesuai dengan kebutuhan peserta didik.

Awal tahun 2020 pemerintah menghimbau masyarakat untuk tetap berada dirumah serta melakukan berbagai kegiatan dari rumah hal tersebut merupakan upaya pencegahan pnyebaran corona virus diseases atau disebut juga dengan COVID-19. Covid-19adalah virus yang pertama 
kali ditemukan daerah wuhan china pada akhir tahun 2019 dan mulai menyebar hingga Indonesia pada awal tahun 2020 tepatnya tanggal 2 maret 2020 pertama kali pemerintah mengumumkan kasus positif Covid-19. Adanya Covid-19memberikan dampak yang signifikan terhadap berbagai sektor, terutama sektor pendidikan. Untuk membantu pemerintah mengurangi rantai penyebaran Covid-19Menteri Pendidikan dan Kebudayaan Nadiem Anwar Makarim mengeluarkan kebijakan kegiatan pembelajran jenjang seolah dasar hingga perguruan tinggi yang biasanya dilakuan dengan tatap muka menjadi dalam jaringan (Daring) atau secara online.

Pembelajaran secara online menuntut para pendidik baik guru maupun dosen untuk lebih kreatif dalam memilih media dan metode yang tepat. Media merupakan faktor eksternal yang dapat mempengaruhi keberhasilan belajar. saat ini sudah banyak aplikasi yang dapat dimanfaatkan sebagai media pembelajaran seperti WhatsApp, Google meet, google classroom, zoom dan lain sebagainya.

Berdasaran hasil observasi yang dilakukan peneliti terhadap mahasiswa semester dua prodi Akidah dan Filsafat Islam UIN Sunan Kalijaga kegiatan pembelajaran daring mata kuliah Sejarah Islam Indonesia lebih sering menggunakan media WhatsApp. Adapun penelitian terdahulu tentang pemanfaatan media WhatsApp untuk pembelajaran yaitu penelitian yang dilakukan oleh Afnibar dan dyla fajhriani (2020) dengan tema "Pemanfaatan WhatsApp Sebagai Media Komunikasi Antara Dosen Dan Mahasiswa Dalam Menunjang Kegiatan Belajar (Studi Terhadap Mahasiswa UIN Imam Bonjol Padang” hasil penelitian tersebut menunjukan bahwa mahasiswa menggunakan WhatsApp untuk berkomunikasi dan belajar dengan dosen selain itu, mahasiswa merasa WhatsApp mempermudah mereka dalam menunjang kegiatan belajar dibandingkan media online lainnya.

Penelitian lain dilakukan oleh Mirzon dkk.(2020) tentang "Efektifitas WhatsApp sebagai Media Belajar Daring” penelitian menggnakan metode survey, hasil survey yang diakukan peneliti kepada 51 orang tua siswa sokolah dasar menunjukan bahwa penggunaan WhatsApp sebagai media pembelajaran daring kurang efektif dalam mencapai tujuan pembelajaran. Hal ini disebabkan berbagai faktor, salah satunya karena kurangnya penjelasan yang komprehensif dari guru.

Berbeda dengan dua kajian penelitian di atas, penelitian ini bertujuan untuk mngetahui tahapan-tahapan penggunaan media WhatsApp untuk pembelajaran daring bagi mahasiswa, mendesripsikan kendala yang dihadapi mahasiswa dan dosen dalam penggunaan media WhatsApp untuk pembelajaran serta solusi untuk mengatasi kendala tersebut.

\section{METODE PENELITIAN}

Penelitian ini termasuk kedalam penelitian deskriptif dengan pendekatan kuantitatif. Penelitian deskriptif adalah penelitian yang di maksudkan untuk menyelidiki suatu keadaan, kondisi, atau hal lain-lain kemudian hasilnya akan dipaparkan dalam bentuk laporan penelitian (Arikunto, 2010). Teknik pengumpulan data yang digunakan adalah observasi partisipasi aktif, wawancara, angket dan dokumentasi. Ketika observasi peneliti ikut terlibat langsung dalam beberapa kegiatan yang dilakukan oleh informan, peneliti menggunaan metode wawancara semi strutur dengan menyiapkan pedoman wawancara terlebih dahulu. Menurut (Sugiyono, 2017), pelaksanaan wawancara semi struktur lebih bebas. Dalam kegiatan wawancara, informan dimintai pendapat juga ide -ide yang berhubungan dengan pokok permasalahan. Yang terakhir adalah dokumentasi menurut (Sugiyono, 2016) dokumentasi digunakan untuk melengkapi data hasil observasi dan wawancara agar hasil dari observasi dan wawancara dapat lebih dipercaya kebenarannya. dokumentasi yang digunakan dalah screenshot penggunaan WhatsApp sebagai media pembelajaran selama pandemi, rekaman wawancara Dan RPS mata kuliah sejarah Islam Indonesia

Adapun instrumen yang digunakan dalam penelitian ini adalah pedoman wawancara yang berisi pertanyaan-pertanyaan yang akan ditanyakan kepada informan dan angket untuk mengetahui persepsi mahasiswa terhadap penggunaan aplikasi WhatsApp sebagai media pembelajaran. 


\section{HASIL TEMUAN DAN PEMBAHASAN}

Media merupakan faktor yang dapat mempengaruhi keberhasilan belajar, terlebih lagi di masa pandemi Covid-19dimana kegiatan pembelajaran tidak dapat dilaksanakan secara tatap muka, hal tersebut menuntut para pendidik untuk lebih inovatif dalam menggunakn media pemblajaran. Kemajuan teknologi dan informasi sangat berpengaruh bagi dunia pendidikan, dengan memanfaatkan teknologi pendidik maupun peserta didik lebih mudah mengakases berbagai materi yang dibutuhkan dan dapat melaksanakan pembelajaran secara jarak jauh. Aplikasi-aplikasi yang sering digunakan untuk mendukung pembelajaran jarak jauh terdiri dari google meet, google class room, zoom, WhatsApp, tetapi umumnya dosen menggunakan WhatsApp sebagai media pembelajaran.

Dalam mengumpulkan data peneliti mneggunakan metode observasi dan wawancara, observasi dilaksanakan dengan mengikuti kegiatan pembelajaran mata kuliah SII melalui grup WhatsApp. Sedangkan wawancara bertujuan untuk mengtahui persepsi mahasiswa tentang efektifitas penggunaan aplikasi WhatsApp dalam pembelajaran. wawancara dilaksanakan secara Video call menggunaan media WhatsApp. Adapun laporan hasil wawancara sebagai berikut:

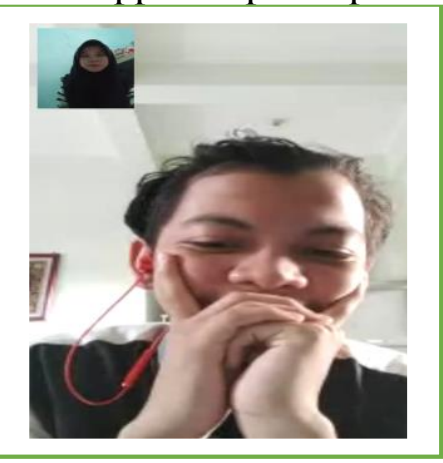

Gambar 1. Hasil Wawancara Mahasiswa (1)

\begin{tabular}{|c|c|c|c|}
\hline \multicolumn{2}{|c|}{ Narasumber } & \multicolumn{2}{|l|}{ A. A } \\
\hline \multicolumn{2}{|c|}{ Kelas } & \multicolumn{2}{|l|}{ AFI/ A } \\
\hline \multicolumn{2}{|c|}{ Asal } & \multicolumn{2}{|l|}{ Kudus } \\
\hline \multicolumn{2}{|c|}{ Tanggal pelaksnaaan } & \multicolumn{2}{|l|}{ 14 Juni 2021} \\
\hline No & \multicolumn{2}{|l|}{ Pertanyaa } & Jawaban \\
\hline 1 & \multicolumn{2}{|c|}{$\begin{array}{l}\text { Apakah aplikasi yang sering digunakan } \\
\text { untuk pembelajaran? }\end{array}$} & $\begin{array}{l}\text { Google classroom, Googlmeet, } \\
\text { zoom meeting, WhatsApp. Media } \\
\text { yang sering digunakan WhatsApp }\end{array}$ \\
\hline 2 & \multicolumn{2}{|c|}{$\begin{array}{l}\text { Dalam sehari, Berapa lama waktu yang } \\
\text { digunakan untuk mengakses WhatsApp } \\
\text { "untuk kegiatan pembelajaran" }\end{array}$} & Maksimal 6-7 jam, tetapi tidak full \\
\hline 3 & \multicolumn{2}{|c|}{$\begin{array}{l}\text { Bagaimana pelaksanaan pembelajaran } \\
\text { menggunakan media WhatsApp }\end{array}$} & $\begin{array}{l}\text { Dosen memulai perkuliahan dengan } \\
\text { mengucapkan salam dan } \\
\text { mendeskripsikan alur kegiatan } \\
\text { perkuliahan mulai dari presensi } \\
\text { sampai dengan penugasan. Untuk } \\
\text { tugas yang biasa diberikan dosen } \\
\text { adalah meresume dalah meresume } \\
\text { salah satu tema yang ada di RPS }\end{array}$ \\
\hline 4 & \multicolumn{2}{|c|}{$\begin{array}{l}\text { Menurut anda, apakah pembelajaran } \\
\text { menggunakan media WhatsApp efektif } \\
\text { untuk tingkat mahasiswa? }\end{array}$} & $\begin{array}{l}\text { Fifty-fifty, untuk kelebihannya } \\
\text { lebih simpel dibandingkan dengan } \\
\text { aplikasi lain, contohnya dari segi } \\
\text { presesnsi dan pemberian tugas. }\end{array}$ \\
\hline
\end{tabular}




\begin{tabular}{|l|l|l|}
\hline & & $\begin{array}{l}\text { Presensi tetap bisa dilakukan } \\
\text { meskipun sedang dalam perjalanan. } \\
\text { Untuk kekurangannya kurang } \\
\text { merasaka suasana perkliahan } \\
\text { karena hanya melalui fitur chat. }\end{array}$ \\
\hline 5 & $\begin{array}{l}\text { Apakah kendala/hambatan yang sering } \\
\text { dihdapi ketika pembelajaran } \\
\text { menggunakan media WhatsApp }\end{array}$ & $\begin{array}{l}\text { Gangguan signal karena tidak ada } \\
\text { Kuota internet, }\end{array}$ \\
\hline 6 & $\begin{array}{l}\text { Bagaimanakah solusi untu mengatasi } \\
\text { hambatan tersebut? }\end{array}$ & $\begin{array}{l}\text { Sebelum perkuliahan mengecek } \\
\text { batre handphone dan mengecek } \\
\text { kuota internet, jika kuota tinggal } \\
\text { sedikit maka membeli kuota terlebih } \\
\text { dahulu. }\end{array}$ \\
\hline
\end{tabular}

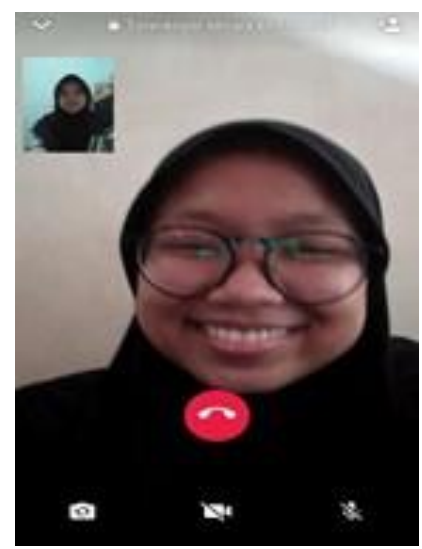

Gambar 2. Hasil Wawancara Mahasiswa (2)

\begin{tabular}{|c|c|c|c|}
\hline \multicolumn{2}{|c|}{ Narasumber } & \multicolumn{2}{|l|}{ R. E } \\
\hline \multicolumn{2}{|c|}{ Kelas } & \multicolumn{2}{|l|}{$\mathrm{AFI} / \mathrm{A}$} \\
\hline \multicolumn{2}{|c|}{ Asal } & \multicolumn{2}{|l|}{ Lampung } \\
\hline \multicolumn{2}{|c|}{ Tanggal pelaksnaaan } & \multicolumn{2}{|l|}{ 14 Juni 2021} \\
\hline No & \multicolumn{2}{|l|}{ Pertanyaa } & Jawaban \\
\hline 1 & \multicolumn{2}{|c|}{$\begin{array}{l}\text { Apakah aplikasi yang sering digunakan } \\
\text { untuk pembelajaran? }\end{array}$} & $\begin{array}{l}\text { WhatsApp, zoom, google meet, } \\
\text { google class room }\end{array}$ \\
\hline 2 & \multicolumn{2}{|c|}{$\begin{array}{l}\text { Dalam sehari, Berapa lama waktu yang } \\
\text { digunakan untuk }\end{array}$} & Sekitar 4-5 jam \\
\hline 3 & \multicolumn{2}{|c|}{$\begin{array}{l}\text { Bagaimana pelaksanaan pembelajaran } \\
\text { menggunakan media WhatsApp }\end{array}$} & $\begin{array}{l}\text { Presensi dengan menyebutkan } \\
\text { nama, nim dan asal, menulis resume } \\
\text { dengan tulis tangan dan } \\
\text { mencantumkan minimal } 3 \text { referensi. } \\
\text { Tugas tersebut secara tidak } \\
\text { langsung membuat mahasiswa } \\
\text { untuk membaca dan memahami } \\
\text { materi. }\end{array}$ \\
\hline 4 & \multicolumn{2}{|c|}{$\begin{array}{l}\text { Menurut anda, apakah pembelajaran } \\
\text { menggunakan media WhatsApp efektif } \\
\text { untuk tingkat mahasiswa? }\end{array}$} & $\begin{array}{l}\text { Penggunaan WhatsApp untuk media } \\
\text { pemelajaran ada sisi positif dan } \\
\text { negatifnya. Sisi positifnya adalah } \\
\text { jika ada mahasiswa yang tidak bisa } \\
\text { mengikuti pembelajaran di jam }\end{array}$ \\
\hline
\end{tabular}




\begin{tabular}{|l|l|l|}
\hline & & $\begin{array}{l}\text { kuliahnya tetap bisa membaca ulang } \\
\text { matri dan informasi-informais yang } \\
\text { tertinggal. Untuk sisi negatifnya } \\
\text { kurangnya interaksi antara dosen } \\
\text { dan mahasiswa, dan jika terus- } \\
\text { terusan menggunakan WhatsApp } \\
\text { dan tidak diselingi dengan media } \\
\text { lain kegiatan belajar menjadi } \\
\text { monoton. }\end{array}$ \\
\hline 5 & $\begin{array}{l}\text { Apakah kendala/hambatan yang sering } \\
\text { dihdapi ketika pembelajaran } \\
\text { menggunakan media WhatsApp }\end{array}$ & $\begin{array}{l}\text { Lebih ke pemahaman, kesulitan } \\
\text { memahami materi }\end{array}$ \\
\hline 6 & $\begin{array}{l}\text { Bagaimanakah solusi untu mengatasi } \\
\text { hambatan tersebut? }\end{array}$ & $\begin{array}{l}\text { Meningatan kesadaran diri, jika ada } \\
\text { materi yang belum dipahami bisa } \\
\text { dengan membaca jurnal dan belajar } \\
\text { diluar jam perkuliahan }\end{array}$ \\
\hline
\end{tabular}
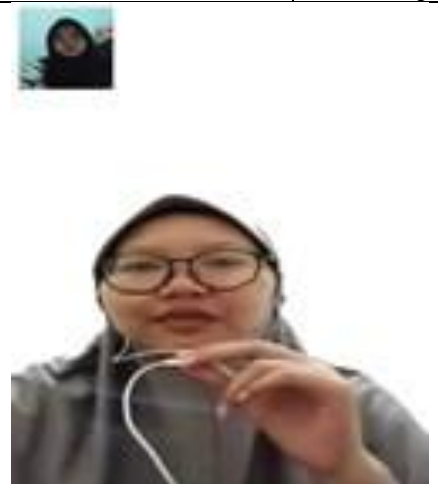

Gambar 3. Hasil Wawancara Mahasiswa (3)

\begin{tabular}{|c|c|c|c|}
\hline \multicolumn{2}{|c|}{ Narasumber } & \multicolumn{2}{|l|}{ N.N } \\
\hline \multicolumn{2}{|c|}{ Kelas } & \multicolumn{2}{|l|}{ AFI/ A } \\
\hline \multicolumn{2}{|c|}{ Asal } & \multicolumn{2}{|l|}{ Majalengka } \\
\hline \multicolumn{2}{|c|}{ Tanggal pelaksnaaan } & \multicolumn{2}{|l|}{ 14 Juni 2021} \\
\hline No & \multicolumn{2}{|l|}{ Pertanyaa } & Jawaban \\
\hline 1 & \multicolumn{2}{|c|}{$\begin{array}{l}\text { Apakah aplikasi yang sering digunakan } \\
\text { untuk pembelajaran? }\end{array}$} & $\begin{array}{l}\text { Googel meet dan zoom meeting } \\
\text { tetapi yang lebih sering diguakan } \\
\text { adalah aplikasi WhatsApp }\end{array}$ \\
\hline 2 & \multicolumn{2}{|c|}{$\begin{array}{l}\text { Dalam sehari, Berapa lama waktu yang } \\
\text { digunakan untuk mengakses WhatsApp } \\
\text { "untuk kegiatan pembelajaran" }\end{array}$} & $\begin{array}{l}\text { Bisa sampai } 2 \text { jam untuk satu mata } \\
\text { kuliah }\end{array}$ \\
\hline 3 & \multicolumn{2}{|c|}{$\begin{array}{l}\text { Bagaimana pelaksanaan pembelajaran } \\
\text { menggunakan media WhatsApp }\end{array}$} & $\begin{array}{l}\text { Dosen memulai perkuliahan dengan } \\
\text { mengirimkan susunan kegiatan } \\
\text { perkuliahan. Dosen memberikan } \\
\text { tugas untuk meresume materi } \\
\text { membuat mahasiswa ada asupan } \\
\text { untuk mmbaca setiap minggunya. } \\
\text { Mengirimkan film pendek tentang } \\
\text { sejarah wali songo. }\end{array}$ \\
\hline 4 & \multicolumn{2}{|c|}{$\begin{array}{l}\text { Menurut anda, apakah pembelajaran } \\
\text { menggunakan media WhatsApp efektif } \\
\text { untuk tingkat mahasiswa? }\end{array}$} & $\begin{array}{l}\text { Cukup efektif karena bisa membaca } \\
\text { ulang atau mengulas materi yang } \\
\text { sudah di sampaikan tetapi ada juga } \\
\text { kekurangannya yaitu }\end{array}$ \\
\hline
\end{tabular}




\begin{tabular}{|l|l|l|}
\hline 5 & $\begin{array}{l}\text { Apakah kendala/hambatan yang sering } \\
\text { dihdapi ketika pembelajaran } \\
\text { menggunakan media WhatsApp }\end{array}$ & $\begin{array}{l}\text { Gangguan signal terutama jika } \\
\text { setelah turun hujan, dan listrik } \\
\text { padam }\end{array}$ \\
\hline 6 & $\begin{array}{l}\text { Bagaimanakah solusi untu mengatasi } \\
\text { hambatan tersebut? }\end{array}$ & $\begin{array}{l}\text { keluar dari rumah Mencari tempat } \\
\text { yang lebih tinggi. }\end{array}$ \\
\hline
\end{tabular}

\section{A. Penggunaan WhatsApp Sebagai media Pembelajaran Selama Pandemi Covid-19 (Studi Kasus Mahasiswa Semester Dua Prodi Akidah Dan Fisafat Islam)}

Berdasaran hasil observai dan wawancara kepada beberapa mahasiswa, maka peneliti mendapatkan hasil sebagai berikut:

Tahap-tahap pembelajaran menggunakan media WhatsApp

1. Perencanaan

Persiapan yang dilakukan dosen sebelum pekuliahan dengan menggunakan media aplikasi WhatsApp adalah dengan membuat RPS yang nantinyaakan disampaikan pada awal perkuliahan, menyiapkan materi berupa power point dan film-film pendek yang berhubungan dengan perkembangan islam di Indonesia, meminta ketua kelas untuk membuat grup WhatsApp.

2. Pelaksanaan

Tahap pelaksanaan adalah realisasi dari perencanan yang telah dibuat sebelumnya. Adapun tahap pelaksanaan sebagai berikut: (1) dosen mengirimkan susunan kegiatan pembelajaran yang diawali dengan salam kemudian (2) mahasiswa diminta untuk presensi dengan mengirimkan nama, nim dan juga alamat, (3) dosen mendeskripsikan tugas yang harus dikerjakan mahasisswa selama jam perkuliahan berlangsung, adapun tugas yang biasanya diberikan dosen adalah resume, mahasiswa diminta untuk membuat ringkasan menggunakan tulisan tangan minimal tiga halaman folio dan tiga referensi dengan tema yang telah ditentukan oleh dosen, (4) terakhir dosen mengakhiri perkuliahan dengan membaca hamdalah dan mengucapkan salam. Dosen akan memberikan klarifikasi atau menjelaskan materi dan melakuan diskusi dengan mahasiswa melalui zoom Setelah beberapa kali perkuliahan dengan media aplikasi WhatsApp.

3. Evaluasi

Pada tahap terakhir yaitu evaluasi, evaluasi pembelajaran menggunakan media WhatsApp dilaksanakan dengan cara memberikan tugas kepada mahasiswa untuk menulis artikel dan mereview kembali materi yang disampaikan, hasil review disampaikan di grup WhatsApp.

Kelebihan media WhatsApp menurut (Pustikayasa, 2019):

1. pendidik dan peserta didik bisa bertanya jawab atau berdiskusi dengan lebih rileks tanpa harus terpusat pada pendidik seperti pembejaran di kelas, yang sering menimbulkan rasa takut salah dan malu pada peserta didik.

2. Dengan media WhatsApp, pendidik dapat lebih berkreasi dalam memberikan materi maupun tugas tambahan kepada peserta didik.

3. Peserta didik dengan mudah bisa mengirim balik hasil pekerjaan, baik berupa komentar langsung (chat group), gambar, video atau soft files lainnya yang berhubungan dengan pembelajaran.

4. Dengan media WhatsApp, metode pembelajaran menjadi ramah lingkungan karena tidak lagi menggunakan hard copy (penggunaan kertas untuk mencetak atau menulis hasil pekerjaan peserta didik).

5. Dengan media WhatsApp, dapat menjadi salah satu solusi pendidik untuk menyampaikan materi tambahan sebagai bahan pembelajaran di luar kelas.

Kekurangan media WhatsApp menurut (Pustikayasa, 2019)

1. Pendidik dan peserta didik harus terhubung dengan layananinternet untuk mendapatkan informasi secara real times. 
2. Komunikasi menggunakan video, gambar dan file yang berukuran besar berpengaruh pada penggunaan data (biaya)

3. Tanpa aturan atau kesepakatan yang jelas oleh admin (pendidik) grup,komunikasi dapat keluar dari kontek pembelajaran

Adapun Kelebihan penggunan aplikasi WhatsApp untuk media pembelajaran dalam penelitian ini adalah; mudah di akses kapanpun sehingga tetap bisa mengikuti perkuliahan meskipun sedang di perjalanan, pengiriman tugas lebih simpel, dapat mengulas kembali materi dan hasil diskusi. Berbeda dengan pernyataan menurut Pustikayasa kekurangan penggunaan WhatsApp sebagai media pembelajaran yaitu mahasiswa kurang aktif bertanya karena kesulitan menyusun kata-kata, kurangnya interaksi antara dosen dan mahasiswa, kesulitan memahami materi.

\section{B. Hambatan Dan Solusi Yang Dihadapi Ketika Menggunakan WhatsApp Sebagai Media Pembelajaran Selama Pandemi Covid-19}

Penelitian terdahulu banyak yang menyimpulkan bahwa Aplikasi WhatsApp cukup efektif digunakan untuk media pembelajaran, namun dalam pelaksanaannyapun tetap ditemukan beberapa kendala seperti:

1. Gangguan signal

Hasil wawancara kepada beberapa mahasiswa tentang hambatan yang sering dihadapi ketika menggunakan aplikasi WhatsApp untuk media pembelajaan, mereka kompak menjawab gangguan signal.gangguan signal disebabkan oleh faktor-faktor seperti tidak adanya kuota internet, curah hujan, dan listrik padam. Adapun solusi yang dilakukan mahasiswa untuk mengatasi kendala tersebut adalah dengan mengecek kuota internet sebelum pembelajaran dimulai, mencari lokasi yang lebih tinggi setelah turun hujan agar signal lebih stabil dan mengecek batre handpone.

2. kesulitan memahami materi

Menurut hasil wawancara beberapa mahasiswa kesulitan untuk memahami materi, terlebih lagi mata kuliah sejarah. Karena di tingkat perguruan tinggi mahasiswa di tuntut untuk berfikir lebih kritis. Mengkritisi sejarah dan mencari smber yang lebih valid. Solusi untuk persoalan tersebut adalah ketika penyampaian kontrak belajar disepakati bersama untuk menggunakan media pembelajaran yang bervariasi, solusi lain adalah dengan menyadari kemampuan diri sendiri jika merasa kurang memahami materinya maka harus mencari tahu diluar jam pembelajaran.

3. kurang interaksi

kurangnya intraksi antara mahasiswa dan dosen bisa disebabkan karena dosen hanya mengirimkan tugas. Selain itu, mahasiswas seringkali kesulitan untuk menyusun kata-kata yang sopan ketika ingin menyampaikan pendapat dan bertanya materi yang belum dipahami. Solusi untuk persoalan tersebut sama dengan point kedua yaitu dengan sesekali melakukan pembelajaran melui video isa menggunakan aplikasi seperti zoom meet dan google meet.

\section{Efektifitas Penggunaan Aplikasi WhatsApp Sebagai Media Pembelajaran Selama Pandemi Covid-19}

Untuk mengetahui efektifitas penggunaan WhatsApp dalam pembelajan, peneliti melakukan survey menggunakan google form. Adapun hasil survey sebagai berikut: 


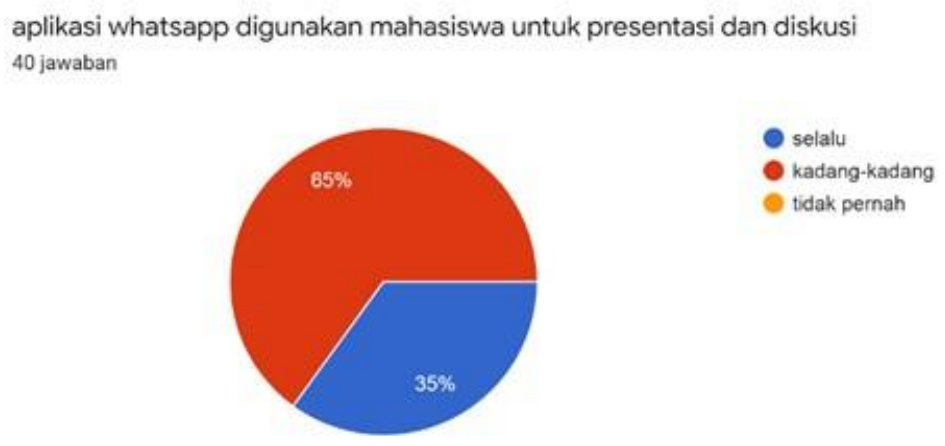

\section{Gambar 7}

Berdasarkan data tersebut aplikasi WhatsApp kadang-kadang digunakan untuk presentasi dan diskusi karena $65 \%$ responden menjawab kadang-kadang, 35\% menjawab selalu dan tidak ada responden yang menjawab tidak pernah.

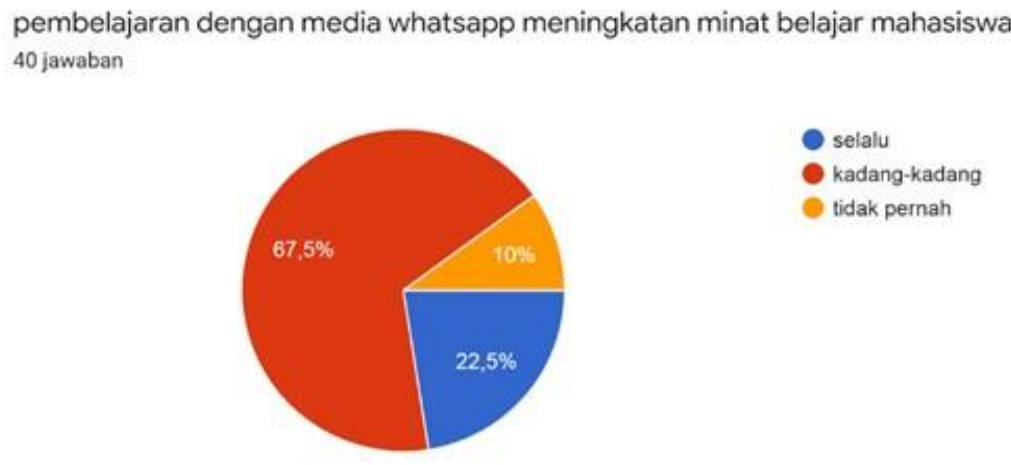

\section{Gambar 8}

Dari data tersebut menunjukan bahwa pembelajaran menggunakan aplikasi WhatsApp meningkatkan minat belajar mahasiswa.

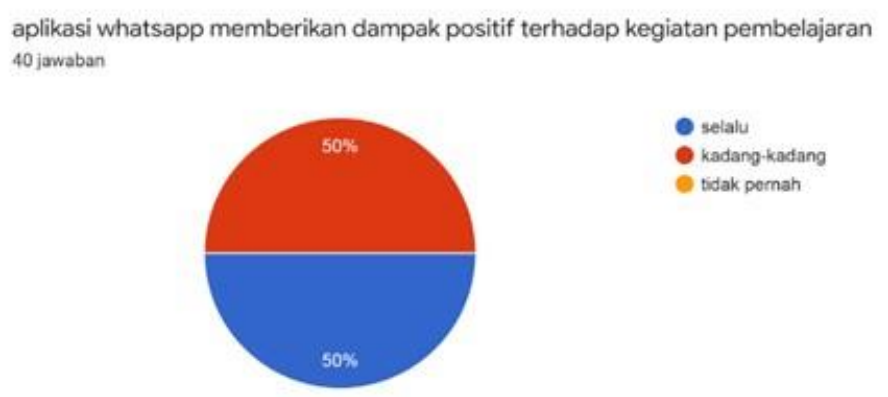

\section{Gambar 9}

Dari data tersebut 20 responden menjawab selalu dan 20 lainnya menjawab kadangkadang, maka dapat diartikan bahwa pembelajaran menggunakan aplikasi WhatsApp memberikan dampa positif. Hasil survey menunjukan bahwa pembelajaran menggunakan media WhatsApp selama pandemi cukup efektif meskipun dalam pelaksanaannya masil ada hambatan-hambatan

\section{KESIMPULAN DAN SARAN}

Hadirnya Virus Covid-19sangat memberikan dampak yang signifikan terutama bagi sektor pendidikan, untuk membantu memutus rantai penularan virus tersebut kegiatan belajar mengajar 
tidak bisa dilaksanakan secara tatap muka. Pendidik maupun peserta didik harus dapat beradaptasi dengan kegiatan pembelajaran jarak jauh. Pemilihan media juga perlu diperhatikan karena dapat mempengaruhi keberhasilan belajar peserta didik. Hasil pnelitian menunjukan bahwa mayoritas pembelajaran menggunakan media WhatsApp karena dirasa lebih mudah dan simpel dalam penggunannya. Penggunaan media WhatsApp di prodi akidah dan filsafat islam pada mata kuliah sejarah islam indonesia cukup efektif adapun tahapannya terdiri dari perencanaan dan pelaksanaan, namun dalam pelaksanaannya masih terdapat beberapa hambatan seprti ganggan signal, kurangnya interaksi dan kesulitan memahami materi. Hasil survey menunjukan bahwa pembelajaran menggunakan media WhatsApp efektif.

\section{DAFTAR PUSTAKA}

Afnibar, 2020."Pemanfaatan Whatsapp Sebagai Media Komunikasi Antara Dosen Dan Mahasiswa Dalam Menunjang Kegiatan Belajar (Studi terhadap Mahasiswa UIN Imam Bonjol Padang)". Al Munir Jurnal Komunikasi Dan Penyiaran Islam. Volume 11. N0. 1.

Arikunto, S. (2010). Prosedur Penelitian (Suatu Pendekatan Praktek). Jakarta: PT. Rineka Cipta. Daheri, Mirzon, dkk.. (2020). "Efektifitas WhatsApp sebagai Media Belajar Daring" JurnalBasicedu. Volume 4 No.4.

Prajana, Andika. (2017). "Pemanfaatan Aplikasi Whatsapp Dalam Media Pembelajaran Di Uin Ar-Raniry Banda Aceh". Jurnal Pendidikan Teknologi Informasi. Volume 1. No. 2.

Pustikayasa, I. M. (2019). Grup WhatsAppSebagai Media Pembelajaran (WhatsApp Group As Learning Media). Widya Genitri : Jurnal Ilmiah Pendidikan, Agama dan Kebudayaan Hindu, Volume 10. No 2

Ricu Sidiq. (2019). Pemanfaatan WhatsApp Group dalam Pengimplementasian Nilai-Nilai Karakter Pancasila Pada Era Disrupsi. Jurnal Putri Hijau Volume 4. No.2 Sugiyono. (2016). Metode Penelitian Pendidikan. Bandung: Alfabeta.

Sugiyono. (2017). Penelitian Kualitatif, Kuantitatid Dan Rnd. Bandung: PT. Alfabeta. 